\title{
CAPÍTULO 14: DESPERTANDO VOCAÇÕES PARA O EMPREENDEDORISMO
}

\section{CAPÍTULO 14: DESPERTAR VOCACIONES PARA EL EMPRENDIMIENTO}

\section{CHAPTER 14: AWAKENING VOCATIONS FOR ENTREPRENEURSHIP}

\section{Rosangela Rodrigues Lima dos Santos ${ }^{1}$; Derek Luiz Alves dos Santos ${ }^{2}$; Emanuel Assuero Silva Costa Alves ${ }^{3}$;} Erick Viana da Silva ${ }^{4}$; Marisa Marinho Fernandes Viana ${ }^{5}$

DOI : https://doi.org/10.31692/978-65-88970-03-4.198-201

\section{INTRODUÇÃO}

Em uma era de globalização com mercados de trabalho altamente acirrados, o empreendedorismo se conjuntura como uma ferramenta de grande importancia para qualquer individuo, que busca o sucesso em suas ações e projetos.

A ação de empreender pode ser dada de variadas maneiras: com a abertura de negócios, por meio de políticas públicas, projetos sociais, bem como, por meio do intraempreendedorismo. Ou seja, nos setores público, privado e sem fins lucrativos, de forma individual ou coletiva.

Essas atitudes empreendedoras devem estar presentes no âmbito acadêmico, tanto nos currículos escolares, quanto por meio de políticas educacionais provocadas pelas instituições. Ademais, tais iniciativas podem emergir a partir dos próprios discentes, por meio da fundação de empresas juniores - EJs, um importante mecanismo de prática laboratorial no processo formativo, que se contextualiza preferencialmente, em caráter de extensão, conforme a Lei no 11.892, de 29 de dezembro de 2008. (BRASIL, 2016)

O presente relato de experiência, objetiva apresentar os resultados parciais advindos do projeto de extensão do IFPE - Campus Recife: Despertando Vocações para o Empreendedorismo: Empresas Juniores no contexto universitário da Cidade do Recife - PE, que trabalha a temática do movimento empresa júnior, juntamente aos estudantes universitários da Cidade do Recife no Estado de Pernambuco.

\section{RELATO DE EXPERIÊNCIA}

O IFPE - Campus Recife, maior unidade de uma instituição pública que ora possui

${ }^{1}$ Graduanda em Gestão de Turismo, Instituto Federal de Pernambuco - IFPE, rrls@ discente.ifpe.e

${ }^{2}$ Mestre, Instituto Federal de Pernambuco - IFPE, derek.alves@ recife.ifpe.edu.br

3 Cursista do Técnico em Refrigeração e Climatização, Instituto Federal de Pernambuco - IFPE, easca@discente.ifpe.edu.br

${ }^{4}$ Mestre, Professor do Instituto Federal de Pernambuco, erick.viana@recife.ifpe.edu.br

${ }^{5}$ Especialista, Faculdade Matenense dos Vales Gerais - INTERVALE, top.marisa@ hotmail.com 
status universitário, até o momento não possui nenhuma empresa júnior como uma realidade. Sendo assim, as motivações para ocorrência do referido problema, entretanto, de uma forma mais imediata e empreendedora, cabe a realização de ações extensionistas fomentadoras e/ou capacitadoras sobre os temas empreendedorismo e empresas juniores, de modo a se divulgar aos conceitos, bem como, os caminhos viabilizadores para uma eventual fundação de uma EJ, assim como já ocorreu em outras universidades públicas e privadas no contexto recifense.

Dentro das instituições educacionais, o empreendedorismo como disciplina começou a ser visto como um instrumento de desenvolvimento econômico e social, a partir de ações isoladas dentro de escolas ou grandes projetos de incentivo a educação empreendedora (DORNELLAS, 2008).

E segundo Melo (2017), o protagonismo estudantil tem como objetivo colocar o discente como protagonista do seu aprendizado, garantindo assim, o desenvolvimento de projetos que despertem seu interesse e contribuam para o seu processo formativo.

O presente trabalho possui uma natureza aplicada, uma vez que se busca gerar conhecimentos dirigidos a soluções de problemas especifícos.

Buscou-se divulgar aos conceitos de empreendedorismo e Ejs, a partir de convite a estudantes universitários da capital pernambucana, por meio das redes sociais: Instagram e WhatsApp, objetivando a participação em evento virtual temático, qual seja: o Ciclo de Palestras - Empreendedorismo \& Empresas Juniores, que, oportunamente, contou com três encontros, realizados por meio da plataforma Google Meet, englobando cada um deles, as seguintes pautas:

1) O Projeto de Extensão DESPERTANDO VOCAÇÕES PARA EMPREENDEDORISMO: Empresas Juniores no contexto universitário em Recife/PE; Conceitos e abordagens gerais sobre Empreendedorismo e Empresas Juniores; e Discussão sobre Protagonismo Estudantil;

2) Formação Jurídica da Empresa Júnior; e Protagonismo Estudantil;

3) Movimento Empresa Júnior - MEJ.

Ademais, as ações seguiram com reuniões técnicas sobre o contexto de fundação de uma EJ, a partir da triagem de estudantes interessados no protagonismo de fundação de uma EJ, contando com a participação de consultores; professores universitários; gestores de instituições educacionais; empresários juniores locais; e de membros da Federação das Empresas Juniores do Estado de Pernambuco - FEJEPE.

Inicialmente foi criado um grupo nas redes sociais (WhatsApp) aberto voltado a estudantes, professores e profissionais da Cidade do Recife, ora interessados no tema, bem como, um posterior grupo de comunicação instantânea (tamém pelo WhatsApp) especificamente direcioando para a formação de grupo de trabalho - GT, esse, composto por 
15 estudantes universitários, ligados ao IFPE - Campus Recife, com foco no desenvolvimento de minutas de documentos (estatuto, regimento interno, plano de negócios, plano acadêmico, etc.) voltados ao processo de fundação da $1^{\mathrm{a}} \mathrm{EJ}$ do referido campus (assembléia(s), eleição de chapas, dentre outros atos), haja vista ser a única instituição de ensino superior pública na capital pernambucana, até então sem a presença de qualquer EJ, em sua realidade.

A articulação com a gestão do IFPE (Campus Recife e Reitoria), foram efetivas, uma vez que a instituição está atualmente aberta e interessada nessa pauta, tendo inclusive, sido aprovada recentemente, a Resulução n 20 de 5 de abril de 2019, que aprova o Regulamento de Empresas Juniores do IFPE, (IFPE, 2019) bem como, promovidos e disponibilizados aos estudantes da instituição, encontros virtuais sobre o tema, em articulação com a FEJEPE que tem se colocado de maneira bastante proativa.

Mesmo em um cenário adverso, como o relacionado ao novo Coronavírus, que ora passou a isolar as pessoas em confinamentos dominiliares, as ações extensionistas tiveram uma continuidade, sendo isso, algo que remeteu os interessados a um contexto de iniciativas criativas e inovadoras, haja vista, a remodelagem geral das ações em curso.

Ademais, é uma realidade o engajamento de mulheres no MEJ, especificamente no IFPE, tendo em vista que tanto o projeto de extensão, quanto o grupo de trabalho, que ora resultou em minutas de documentos, bem como, em uma chapa gestora única (na eleição), ora voltados para a fundação da respectiva EJ, serem oportunamente encabeçadas por elas, estudantes dos cursos superiores, ou seja, alunas e alunos juntos, em uma equipe composta por ambos os gêneros. O projeto de extensão, bem como o GT, contaram desde o início, com uma equipe mista, tanto no seguimento discente, quanto no docente e técnico-administrativo, estes últimos, enquanto colaboradores e orientadores.

\section{CONCLUSÕES}

Houve interesse por parte de alunos dos cursos superiores da instituição IFPE Campus Recife em ter uma empresa júnior fundada na entidade, haja vista que os mesmos mobilizaram-se a colaborar com essa ideia, de modo a se discutir os pormenores, assim como, todo o passo a passo para a efetiava fundação da $1^{\mathrm{a}}$ empresa júnior do referido campus. Houve assim, um marco empreendedor advindo do protagonismo estudantil.

As ações extensionistas do citado projeto, continuam em andamento, no sentido de contribuição e alanque do processo de expansão do MEJ para outras instituições de ensino supeior da Cidade do Recife, porém, dentro das possibilidades impostas pelo cenário da pandemia da COVID-19 a qual o mundo vivencia, isso, a partir de adaptações realizadas no 
trajeto das ações em curso, pelas quais ocorreram de formas remota e virtual.

\section{REFERÊNCIAS}

BRASIL. Lei $\mathbf{n}^{\mathbf{0}}$ 13.267, de 06 de abril de 2016. Disciplina a criação e a organização das associações denominadas empresas juniores, com funcionamento perante instituições de ensino superior. Disponível em: <http://www.planalto.gov.br/ccivil_03/_ato20152018/2016/lei/L13267.htm>. Acesso em: 01 set. 2020.

DORNELAS, José Carlos Assis. Empreendedorismo: transformando ideias em negócios - 3. ed. - Rio de Janeiro. Elsevier, 2008 - $2^{\circ}$ reimpressão.

MELO, R. Protagonismo do aluno: o que é e qual é a sua importância? 2017. Disponível em: <https://blog.estantemagica.com.br/o-que-e-protagonismo-do-aluno/>. Acesso em: 01 set. 2020.

IFPE - INSTITUTO FEDERAL DE PERNAMBUCO. Resulução $\mathbf{n}^{0} \mathbf{2 0}$ de 5 de abril de 2019. Aprova o Regulamento de Empresas Juniores do IFPE. Disponível em: <https://www.ifpe.edu.br/o-ifpe/conselho-superior/resolucoes/resolucoes-2019>. Acesso em: 01 set. 2020. 